\title{
KEMAMPUAN EKSAKTA MAHASISWA FAKULTAS ILMU TARBIYAH DAN KEGURUAN
}

\author{
Rini Warti \& Try Susanti \\ e-mail: rini_warti@yahoo.co.id \\ Pendidikan Matematika, IAIN STS, Jambi
}

\begin{abstract}
Abstrak: Hasil belajar mahasiswa dipengaruhi oleh faktor internal dan eksternal. Penelitian ini bertujuan untuk mengetahui faktor-faktor yang mempengaruhi kemampuan eksakta mahasiswa Fakultas Ilmu Tarbiyah dan Keguruan IAIN STS Jambi. Penelitian kuantitatif deskriptif ini dilaksanakan Juli - Oktober 2013. Data diperoleh dari penyebaran angket dan dokumentasi nilai akhir matakuliah Matematika Dasar, Biologi Umum, Kimia Dasar dan Fisika Dasar dari 194 orang mahasiswa angkatan 2012. Dari angket diperoleh 2 peubah kuantitatif dan 16 peubah kualitatif. Peubah kualitatif diubah menjadi kuantitatif menggunakan peubah boneka (dummy) dan selanjutnya dianalisis dengan regresi dummy. Hasilnya, diperoleh tiga faktor yang sangat signifikan mempengaruhi kemampuan eksakta mahasiswa, yaitu status menikah, jurusan ketika berada di sekolah menengah, dan pilihan jurusan. Hasil analisis lanjut menunjukkan bahwa mahasiswa dengan status sudah menikah memiliki resiko (odds ratio) sebesar 2,15 kali dari mahasiswa yang belum menikah untuk memperoleh nilai di bawah rata-rata; mahasiswa dari jurusan IPA beresiko 0,33 kali dari mahasiswa non IPA; dan mahasiswa yang memilih jurusan saat ini pada pilihan pertama beresiko 0,75 kali dari mahasiswa yang memilih pada pilihan selainnya dalam memperoleh nilai eksakta di bawah rata-rata. Oleh karena itu, untuk meningkatkan kemampuan eksakta mahasiswa Jurusan Pendidikan Matematika, Fisika dan Biologi perlu mensyaratkan jurusan IPA dalam proses penyaringan calon mahasiswa.
\end{abstract}

Kata-kata kunci: hasil belajar, eksakta, regresi dummy, odds ratio

\section{DESCRIPTION OF THE STUDENTS' EXACT CAPABILITIES AT THE FACULTY OF TARBIYAH AND TEACHING}

\begin{abstract}
The students' achievement are influenced by internal and external factors. The aim of this research was to determine the factors that affect the students' exact capability at The Faculty Tarbiyah and Teaching, IAIN, STS Jambi. The data were obtained from the questionnaire and documentation of student achievement in basic mathematics, general biology, basic chemistry and physics from 194 students of 2012 registration. The questionnaire consisted of two quantitative variables and 16 qualitative variables. The qualitatif variables were transformed into quantitative using dummy variables and analyzed with regression dummy. The analysis shows three factors that significantly affect the students' exact capability, i.e marriage status, majoring in secondary schools, and the choice of majors in the university. Further analysis shows, the students with married status have an odds ratio of 2,15 times of the students who have not married in obtaining the score under the average; the students from major IPA have an odds ratio 3,33 times of non IPA students. The students who chose the present majors as the first option have an odds ratio 0,75 times of students who chose other majors in obtaining exact scores under the average. Therefore, to improve the ability of the exact students of mathematics, physics and biology, should science majors should become a rquirement in selecting prospective students.
\end{abstract}

Keywords : students achievement, exact, regression dummy, odds ratio

\section{PENDAHULUAN}

Pendidikan merupakan salah satu upaya untuk mencerdaskan kehidupan bangsa di berbagai aspek kehidupan manusia. Pendidikan juga memegang peranan penting dalam upaya meningkatkan kualitas sumber daya manusia. Untuk itu, peningkatan mutu pendidikan harus dimulai dari pendidikan dasar hingga sampai ke pendidikan tinggi. Hal ini bertujuan untuk menciptakan manusia yang berkompeten, hingga mampu menghadapi setiap perubahan dan permasalahan yang terus berkembang. Paparan tersebut sesuai dengan definisi pendidikan yang diatur dalam UU RI Nomor 12 Tahun 2012 tentang Sistem Pendidikan Nasional, yang menjelaskan bahwa pendidikan adalah usaha sadar dan terencana untuk mewujudkan suasana belajar dan proses pembelajaran agar peserta didik secara aktif mengembangkan potensi 
dirinya untuk memiliki kekuatan spiritual keagamaan, pengendalian diri, kepribadian, kecerdasan, akhlak mulia, serta keterampilan yang diperlukan dirinya, masyarakat, bangsa, dan negara (Anonim, 2012).

Pendidikan sebagai investasi bangsa, maka pendidikan perlu dikelola secara baik dan terpadu dalam rangka meningkatkan kualitas sumber daya manusia yang dihasilkan sesuai dengan tujuan yang telah ditetapkan. Peningkatan kualitas pendidikan di setiap satuan pendidikan diarahkan pada upaya terselenggaranya layanan pendidikan yang terjangkau oleh masyarakat dan berkualitas. Untuk mengetahui kualitas pendidikan, di setiap satuan pendidikan dapat dilakukan dengan menyelenggarakan penilaian terhadap hasil belajar siswa.

Perguruan tinggi sebagai tempat berkumpulnya masyarakat ilmiah memiliki peran yang sangat penting dalam membentuk sumber daya manusia berkualitas sebagaimana yang tercantum dalam tridarma perguruan tinggi. Kualifikasi sumber daya manusia yang berkualitas ditandai oleh tiga domain, yaitu: (a) kognitif yang ditampilkan dalam berfikir; (b) afektif yang ditampilkan dalam sikap, motivasi, apresiasi perasaan dan penyesuaian diri; serta (c) domain psikomotorik. Proses pendidikan di perguruan tinggi pada prinsipnya tidak akan terlepas dari sasaran domain-domain tersebut, walaupun pada kenyataannya masih banyak mahasiswa yang belum bersungguh-sungguh dalam menjalankan perannya. Sebagian dari mahasiswa beranggapan bahwa kegiatan perkuliahan hanya kegiatan formalitas untuk mengisi waktu luang setelah menyelesaikan pendidikan sekolah menengah tingkat atas dan menghindari pengangguran. Akibatnya, banyak mahasiswa yang asal memilih jurusan di perguruan tinggi yang kadang-kadang sangat bertolak belakang dengan jurusan yang diperoleh di sekolah menengah tingkat atas. Hal ini harus segera ditanggulangi karena akan mempengaruhi potensi mahasiswa.

Institut Agama Islam Negeri Sulthan Thaha Saifuddin (IAIN STS) Jambi sebagai salah satu perguruan tinggi Islam terus berusaha meningkatkan mutu lulusan dengan cara meningkatkan fasilitas pembelajaran dan pembaharuan kebijakan. Namun, kebutuhan akan jumlah mahasiswa seakan sedikit menghambat upaya tersebut. Kualitas mahasiswa yang mendaftar yang banyak menjadikan IAIN STS Jambi sebagai pilihan kedua jika tidak diterima di universitas negeri merupakan salah satu faktor penghambat tersebut. Kondisi diperparah dengan pemilihan jurusan di IAIN STS Jambi yang banyak sekali tidak sesuai dengan latar belakang pendidikan calon mahasiswa baru, padahal hal tersebut merupakan syarat utama dalam mempermudah mahasiswa mengikuti proses perkuliahan nantinya. Akibatnya, dosen yang mengajar sering mengeluh dan memiliki kesulitan dalam melaksanakan proses perkuliahan di dalam kelas, bukan hanya karena kemampuan mahasiswa yang beragam tetapi sangat rendahnya kemampuan awal yang dimiliki oleh mahasiswa dalam suatu mata kuliah.

Fakultas Ilmu Tarbiyah dan Keguruan (FITK) adalah salah satu fakultas yang mengalami fenomena di atas. Jurusan Pendidikan Matematika, Fisika dan Biologi sebagai program keahlian eksakta sangat banyak memperoleh calon mahasiswa baru yang berasal dari jurusan selain Ilmu Pengetahuan Alam (IPA) ketika di sekolah menengah tingkat atas khususnya Sekolah Menengah Atas (SMA) dan Madrasah Aliyah (MA). Bahkan, kadangkadang mahasiswa juga berasal dari jenjang Sekolah Menengah Kejuruan (SMK) seperti jurusan tata boga, tata busana, sekretaris dan sebagainya. Lemahnya kemampuan eksakta mahasiswa yang berasal dari jurusan tersebut, tentu saja cukup mengganggu kelancaran proses penyampaian materi perkuliahan. Terkadang dosen harus mengulangi konsep-konsep dasar yang ada di sekolah menengah dan mengulangi penjelasan beberapa kali mengingat cukup beragamnya kemampuan dan pengetahuan awal mahasiswa.

Meskipun proses pemilihan jurusan para mahasiswa baru di IAIN STS Jambi sering menjadi keluhan para dosen yang mengajar, namun tidak sampai mengganggu kelancaran proses perkuliahan. Dalam beberapa kasus, ada mahasiswa yang berasal dari selain jurusan IPA memiliki hasil belajar yang tinggi. Artinya, apapun jurusan calon mahasiswa ketika berada di sekolah menengah tingkat atas sebenarnya tidak menjadi tolak ukur dalam memilih jurusan di perguruan tinggi, tetapi bergantung pada ketekunan dan keaktifan mahasiswa dalam belajar. Hal ini mendorong peneliti untuk menyelidiki faktorfaktor yang mempengaruhi kemampuan eksakta mahasiswa Jurusan Pendidikan Matematika, Fisika dan Biologi di FITK IAIN STS Jambi.

Studi kasus pada penelitian ini adalah mahasiswa angkatan 2012 dari Jurusan Pendidikan Matematika, Fisika dan Biologi. Kemampuan eksakta yang digunakan dalam penelitian ini adalah dokumentasi nilai akhir mahasiswa dari empat mata kuliah yang meliputi Matematika Dasar, Kimia Dasar, Biologi Umum dan Fisika Dasar. Nilai ini berbentuk angka sebagai gambaran dan kemampuan 
kognitif yang dikuasai mahasiswa sebagai akibat dari proses perkuliahan semester awal di FITK IAIN STS Jambi. Sedangkan faktor-faktor yang mempengaruhi kemampuan eksakta mahasiswa meliputi faktor intern dan faktor ekstern (Slameto, 2010). Faktor-faktor ini menghasilkan dua jenis peubah, yaitu kuantitatif dan kualitatif, maka pada penelitian ini akan dibentuk model regresi dummy untuk melihat keterkaitan antar peubah-peubah.

Peubah dummy (boneka) adalah salah satu metode untuk mengkuantitatifkan peubah kualitatif dalam model persamaan regresi (Widarjono, 2010). Secara umum banyaknya peubah dummy yang dibutuhkan adalah banyaknya kategori pada peubah kualitatif dikurangi 1. Cara pemberian kode dummy umumnya menggunakan kategori yang dinyatakan dengan angka 1 dan 0 . Kedua nilai yang diberikan tidak menunjukkan bilangan (numerik), tetapi hanya sebagai identifikasi kelas atau kategorinya (Draper \& Smith, 1992). Dalam analisis regresi sering kali bukan hanya peubah penjelas kuantitatif yang mempengaruhi peubah respon $(\mathrm{Y})$, tetapi juga peubah kualitatif yang ikut juga mempengaruhi (Asmawi, 2005). Oleh karena itu, peubah dummy digunakan sebagai upaya untuk melihat bagimana klasifikasi-klasifikasi dalam sampel berpengaruh terhadap parameter pendugaan.

Berdasarkan uraian diatas, diyakini bahwa analisis regresi dummy dapat digunakan untuk menyelidiki faktor-faktor yang mempengaruhi kemampuan eksakta mahasiswa Jurusan Pendidikan Matematika, Fisika dan Biologi di FITK IAIN STS Jambi. Adapun tujuan dari penelitian ini adalah untuk (1) Membentuk model regresi dummy dari peubah-peubah bebas yang diasumsikan, (2) Menentukan faktor-faktor yang berpengaruh signifikan terhadap kemampuan eksakta mahasiswa, (3) Membandingkan klasifikasi-klasifikasi dalam sampel terhadap parameter dugaan yang signifikan mempengaruhi kemampuan eksakta mahasiswa Jurusan Pendidikan Matematika, Fisika dan Biologi di FITK IAIN STS Jambi.

\section{METODE PENELITIAN}

Penelitian yang dilaksanakan adalah penelitian kuantitatif deskriptif. Penelitian ini dilaksanakan pada Juli - Oktober 2013 bertempat di FITK IAIN STS Jambi khususnya pada Jurusan Pendidikan Matematika, Fisika dan Biologi. Sampel dalam penelitian ini adalah 194 orang mahasiswa angkatan 2012 pada Jurusan Pendidikan Matematika, Fisika dan Biologi di FITK IAIN STS Jambi. Sampel dipilih dengan teknik total sampling. Data yang digunakan dalam penelitian ini adalah data primer hasil belajar empat mata kuliah dan angket yang diberikan kepada mahasiswa yang menjadi sampel penelitian. Hasil belajar merupakan peubah respon sedangkan butir pertanyaan dalam angket menghasilkan 16 peubah penjelas. Hasil belajar merupakan peubah respon yang berbentuk kuantitatif, sedangkan jumlah saudara merupakan peubah penjelas yang berbentuk kuantitatif.

Data yang terkumpul dianalisis untuk menguji hipotesis yang telah dikemukakan dengan langkahlangkah (a) Mengubah peubah kualitatif menjadi peubah kuantitatif dengan menggunakan kode 0 dan 1; (b) Membuat model dugaan awal kemampuan eksakta berdasarkan peubah respon dan peubah penjelas yang digunakan; (c) Melakukan penyeleksian peubah untuk memperoleh model hasil belajar terbaik dengan melakukan pengujian secara simultan dengan uji-F dan pengujian secara parsial dengan uji-t; dan (d) Melakukan penghitungan nilai odds ratio terhadap peubah yang terseleksi untuk melihat perbandingannya.

\section{HASIL DAN PEMBAHASAN}

Untuk mengetahui faktor-faktor yang mempengaruhi kemampuan eksakta mahasiswa Jurusan Pendidikan Matematika, Fisika dan Biologi di FITK IAINSTS Jambi dilakukan dengan menggunakan analisis regresi dummy. Hasil pengujian secara simultan terlihat pada tabel 1 .

Tabel 1. Analisis ragam

\begin{tabular}{|c|c|c|c|c|c|}
\hline $\begin{array}{c}\text { Sumber } \\
\text { Keragaman }\end{array}$ & Db & JK & KT & $\begin{array}{c}\text { Nilai } \\
\text { F }\end{array}$ & Pr $>$ F \\
\hline Model & 17 & 766,88 & 45,11 & 2,94 & $0,000^{*}$ \\
\hline Galat & 175 & 2688,59 & 15,36 & & \\
\hline Total & 192 & 3455,47 & & & \\
\hline
\end{tabular}

Tabel 1 menunjukkan nilai F yang signifikan, akibatnya hipotesis nol ditolak, artinya bahwa minimal ada satu faktor yang mempengaruhi kemampuan eksakta mahasiswa. Selanjutnya dilakukan pengujian secara parsial untuk mengetahui peubah yang signifikan dalam model. Hasil pengujian dapat dilihat pada tabel 2 .

Tabel 2. Hasil Uji Parsial

\begin{tabular}{|c|c|c|c|c|}
\hline Peubah & $\begin{array}{c}\text { Parameter } \\
\text { dugaan }\end{array}$ & $\begin{array}{c}\text { Galat } \\
\text { baku }\end{array}$ & Nilai t & Pr $>\mathbf{F}$ \\
\hline Intercept & 70,525 & 2,010 & 35,09 & 0,000 \\
\hline Saudara & $-0,0145$ & 0,1771 & $-0,08$ & 0,935 \\
\hline Jenis kelamin & $-0,3776$ & 0,6398 & $-0,59$ & 0,556 \\
\hline Domisili & 0,5830 & 0,6706 & 0,87 & 0,386 \\
\hline Menikah & $-5,326$ & 2,481 & $-2,15$ & $0,033^{*}$ \\
\hline
\end{tabular}

Perspektif Ilmu Pendidikan - Vol. 28 No. 2 Oktober 2014 


\begin{tabular}{|c|c|c|c|c|}
\hline Peubah & $\begin{array}{c}\text { Parameter } \\
\text { dugaan }\end{array}$ & $\begin{array}{c}\text { Galat } \\
\text { baku }\end{array}$ & Nilai t & Pr $>$ F \\
\hline Bekerja & $-0,833$ & 1,007 & $-0,83$ & 0,409 \\
\hline Pend. ayah & 1,1873 & 0,7583 & 1,57 & 0,119 \\
\hline Pek. ayah & $-0,9577$ & 0,6640 & $-1,44$ & 0,151 \\
\hline Pend. ibu & $-0,6551$ & 0,7833 & $-0,84$ & 0,404 \\
\hline Pek. ibu & $-0,1621$ & 0,6267 & $-0,26$ & 0,796 \\
\hline Pendapatan & 0,5831 & 0,6373 & 0,92 & 0,361 \\
\hline Asal sekolah & $-0,3194$ & 0,6863 & $-0,47$ & 0,642 \\
\hline Status sekolah & $-0,4218$ & 0,6700 & $-0,63$ & 0,530 \\
\hline Jurusan & 2,8596 & 0,6979 & 4,10 & $0,000^{*}$ \\
\hline Proses masuk & 0,3613 & 0,8109 & 0,45 & 0,656 \\
\hline Pilihan & $-1,3282$ & 0,6241 & $-2,13$ & $0,035^{*}$ \\
\hline Informasi IAIN & 0,9523 & 0,9876 & 0,96 & 0,336 \\
\hline Menyukai & 0,033 & 1,498 & 0,02 & 0,982 \\
jurusan & & & & \\
\hline
\end{tabular}

Keterangan : *signifikan pada taraf $a=0,05$

Hasil uji parsial menunjukkan bahwa peubah menikah, jurusan dan pilihan yang signifikan, artinya hanya ketiga peubah ini yang merupakan faktor yang paling besar pengaruhnya terhadap kemampuan eksakta mahasiswa. Model kemampuan eksakta mahasiswa yang terbentuk adalah :

kemampuan eksakta $=70,7-5.07$ menikah +2.68 jurusan-1.19 pilihan+ $\varepsilon$

Dapat disimpulkan bahwa jurusan mahasiswa ketika berada disekolah menengah akan mempengaruhi nilai yang diperoleh untuk mata kuliah Matematika Dasar, Fisika Dasar, Kimia Dasar dan Biologi Umum, karena sebagian besar konsep dasar materi pada keempat mata kuliah ini sudah mahasiswa dapatkan ketika berada di sekolah menengah. Kemampuan eksakta ini juga dipengaruhi oleh pilihan jurusan yang mahasiswa lakukan ketika mendaftar di IAIN STS Jambi serta status mahasiswa.

Untuk faktor menikah, peubah menikah yang diperoleh melalui angket dibagi menjadi dua kategori yaitu sudah dan belum menikah. Hasil analisis menikah terhadap kemampuan eksakta dapat dilihat pada Tabel 3.

Tabel 3. Tabel Kontingensi untuk Menikah

\begin{tabular}{|c|c|c|c|}
\hline \multirow{2}{*}{ Menikah } & \multicolumn{2}{|c|}{ Kemampuan Eksakta } & \multirow{2}{*}{ Total } \\
\cline { 2 - 3 } & $\mathbf{2 7 1 , 2 9}$ & $\mathbf{2 7 1 , 2 9}$ & \\
\hline Sudah & 2 & 1 & 3 \\
\hline Belum & 92 & 99 & 191 \\
\hline Total & 94 & 100 & 194 \\
\hline
\end{tabular}

Dari tabel 3 diketahui bahwa hampir seluruh mahasiswa berstatus belum menikah dan sebanyak 100 orang atau 51,55\% mahasiswa memperoleh nilai di atas 71,29 artinya sebagian besar mahasiswa, baik dengan status sudah dan belum menikah memperoleh nilai diatas rata-rata. Dari data diperoleh nilai odds ratio sebesar 2,15 artinya mahasiswa dengan status sudah menikah memiliki resiko sebesar 2,15 kali lipat untuk memperoleh nilai dibawah rata-rata dibandingkan dengan mahasiswa yang belum menikah.

Peubah jurusan yang diperoleh melalui angket dibagi menjadi dua kategori yaitu IPA dan non IPA. Hasil analisis jurusan terhadap kemampuan eksakta dapat dilihat pada Tabel 4 .

Tabel 4. Tabel Kontingensi untuk Jurusan

\begin{tabular}{|c|c|c|c|}
\hline \multirow{2}{*}{ Jurusan } & \multicolumn{2}{|c|}{ Kemampuan Eksakta } & \multirow{2}{*}{ Total } \\
\cline { 2 - 3 } & $\mathbf{2 7 1 , 2 9}$ & $\mathbf{2 7 1 , 2 9}$ & \\
\hline IPA & 34 & 63 & 97 \\
\hline Non IPA & 60 & 37 & 97 \\
\hline Total & 94 & 100 & 194 \\
\hline
\end{tabular}

Dari tabel 4 diketahui bahwa jumlah sampel yang berlatar belakang jurusan IPA dan nonIPA sama banyak dan sebanyak 100 orang atau 51,55\% mahasiswa memperoleh nilai diatas 71,29 artinya sebagian besar mahasiswa baik yang berasal dari jurusan IPA maupun nonIPA memperoleh nilai diatas rata-rata. Dari data diperoleh nilai odds ratio sebesar 0,33 artinya mahasiswa yang berasal dari jurusan IPA ketika berada di sekolah menengah memiliki resiko sebesar 0,33 kali lipat untuk memperoleh nilai dibawah rata-rata dibandingkan dengan mahasiswa yang berasal dari jurusan nonIPA.

Peubah pilihan jurusan yang diperoleh melalui angket dibagi menjadi dua kategori yaitu pilihan pertama dan selainnya (pilihan kedua atau ketiga). Hasil analisis pilihan jurusan terhadap kemampuan eksakta dapat dilihat pada Tabel 5.

Tabel 5. Tabel Kontingensi untuk Pilihan Jurusan

\begin{tabular}{|c|c|c|c|}
\hline \multirow{2}{*}{ Pilihan } & \multicolumn{2}{|c|}{ Kemampuan Eksakta } & \multirow{2}{*}{ Total } \\
\cline { 2 - 3 } & $\mathbf{2 7 1 , 2 9}$ & $\mathbf{2 7 1 , 2 9}$ & \\
\hline Pertama & 83 & 91 & 174 \\
\hline Selainnya & 11 & 9 & 20 \\
\hline Total & 94 & 100 & 194 \\
\hline
\end{tabular}

Dari tabel 5 diketahui bahwa sampel didominasi oleh mahasiswa yangmenjadikan jurusannya saat ini sebagai pilihan pertama ketika mendaftar di IAINSTS Jambi dan sebanyak 100 orang atau 51,55\% mahasiswa memperoleh nilai diatas 71,29 artinya sebagian besar mahasiswa baik memilih jurusannya saat ini sebagai pilihan pertama atau lainnya memperoleh nilai diatas 
rata-rata. Dari data diperoleh nilai odds ratio sebesar 0,75 artinya mahasiswa yang memilih jurusannya sebagai pilihan pertama memiliki resiko sebesar 0,75 kali lipat untuk memperoleh nilai dibawah rata-rata dibandingkan dengan mahasiswa yang menjadikan jurusannya saat ini sebagai pilihan kedua atau ketiga.

\section{PENUTUP}

Hasil analisis dengan regresi dummy terhadap 17 peubah yang merupakan faktor-faktor yang mempengaruhi kemampuan eksakta diperoleh 3 peubah yang signifikan berpengaruh terhadap kemampuan eksakta mahasiswa Jurusan Pendidikan Matematika, Fisika dan Biologi yaitu menikah, jurusan ketika berada di sekolah menengah dan pilihan jurusan. Hasil analisis menunjukkan nilai $\mathrm{R}^{\wedge} 2=0,222$ yang artinya bahwa skor kemampuan eksakta mahasiswa hanya dipengaruhi sebesar 22,2\% oleh ketiga peubah sedangkan sisanya 77,8\% dijelaskan oleh faktor-faktor lain yang tidak terungkap melalui angket yang peneliti sebarkan.
Faktor-faktor yang mempengaruhi kemampuan eksakta mahasiswa akan lebih terlihat jika dilengkapi dari faktor ekstern dan intern yang lainnya serta menggunakan instrumen tes dalam memperoleh skor hasil belajar mahasiswa.

\section{DAFTAR PUSTAKA}

Anonim. (2012). UU RI No 12 Tahun 2012. Sistem pendidikan di Indonesia.

Juanda, B. (2009). Ekonometrika: Pemodelan dan pendugaan. Bogor: IPB Press.

Draper, N. Smith, H. (1992). Analisis regresi terapan. Jakarta: PT. Gramedia Pustaka Utama.

Hasan, I. (2004). Analisis data penelitian dengan statistik. Jakarta: Bumi Aksara.

Lestari, P.,\& Suparlinah, I. (2010). Analisis faktor-faktor yang mempengaruhi prestasi akademik mahasiswa pada mata kuliah pengantar akuntansi. Semarang: Fakultas Ekonomi Universitas Soedirman.

Slameto. (2010). Belajar dan faktor-faktor yang mempengaruhinya. Jakarta: Rineka Cipta. 